\title{
MODEL KANO DALAM MENGUKUR KEPUASAN PELANGGAN DI RESTAURAN CEPAT SAJI
}

\author{
Hendy Tannady, Riky Mulyadi \\ Program Studi Teknik Industri \\ Fakultas Teknologi \& Desain \\ Universitas Bunda Mulia \\ hendytannady@yahoo.com
}

\begin{abstract}
ABSTRAK
McD merupakan salah satu restauran cepat saji yang cukup terkenal di Indonesia. Pada penelitian ini akan dibahas apa saja layanan yang diberikan oleh McD serta bagaimana tingkat kepuasan konsumen terhadap atribut pelayanan tersebut. Metode yang digunakan adalah Kano. Dengan metode ini akan diketahui atribut apa saja yang butuh perbaikan dan mana yang disukai oleh konsumen.
\end{abstract}

Kata Kunci : Pelayanan, Kepuasan Konsumen, Kano.

\section{PENDAHULUAN}

Dalam menjalankan bisnis, hal yang terpenting adalah pelayanan yang diberikan sesuai dengan harapan pelanggan. Oleh karena itu, perlu dilakukan proses mencari tahu seberapa besar tingkat kepuasan konsumen terhadap layanan sebuah produk. Ini bertujuan untuk mengetahui seberapa baik suatu perusahaan atau pemilik bisnis memberikan pelayanan terbaik. Selain itu dengan mengetahui tingkat kepuasan konsumen, dapat diketahui juga bagian mana yang perlu diperbaiki, serta yang perlu dipertahankan. Kepuasan pelanggan tidak dapat dianggap remeh hal ini mampu mempengaruhi seberapa besar keinginan pelanggan untuk melakukan repeat order dan menjadi pelanggan tetap

Banyak cara yang dapat dilakukan untuk mencari tahu seberapa besar tingkat kepuasan konsumen terhadap suatu produk. Salah satunya adalah dengan menggunakan metode kano. Untuk dapat lebih memahami tentang prinsip dan cara penyelesaian dalam mempelajari metode kano, maka diperlukan studi kasus terhadap suatu produk atuu jasa yang ditawarkan.

Pada studi kasus ini dilakukan terhadap restoran cepat saji yang berasal dari Amerika, McD. McD dipilih karena termasuk restoran cepat saji yang cukup terkenal di Indonesia.

Tujuan dilakukan penelitian ini adalah untuk dapat mengetahui layanan apa saja yang dianggap penting serta memuaskan yang diberikan oleh McD. Metode Kano mampu membedakan pelayanan menjadi berbagai atribut dan membaginya berdasarkan mana yang memuaskan konsumen.

\section{LANDASAN TEORI}

\section{A. Model Kano}

Model Kano merupakan suatu model yang bertujuan mengkategorikan atributatribut dari produk atau jasa berdasarkan seberapa baik produk/jasa tersebut mampu memuaskan kebutuhan pelanggan. Model ini dikembangkan oleh Profesor Noriaki Kano dari Universitas Tokyo Rika (Kano, 1985). Profesor Noriaki Kano bekerjasama dengan para mahasiswanya memunculkan beberapa ide yang menjadi cikal bakalnya. Dalam metode Kano, kategori dari suatu produk dapat dibedakan menjadi :

1. Must-be atau Basic needs atau Thereshold : pelanggan tidak puas apabila kinerja dari atribut yang bersangkutan rendah. Tetapi kepuasan pelanggan tidak akan meningkat jauh diatas netral meskipun kinerja dari atribut tersebut tinggi. 
2. One dimensional atau performance needs atau linear: tingkat kepuasan pelanggan berhubungan linier dengan kinerja atribut, sehingga kinerja atribut yang tinggi akan mengakibatkan tingginya kepuasan pelanggan pula.

3. Attractive atau Excitement needs atau delighters : tingkat kepuasan pelanggan akan meningkat sangat tinggi dengan meningkatnya kinerja atribut. Akan tetapi penurunan kinerja atribut tidak akan menyebabkan penurunan tingkat kepuasan.

4. Reverse apabila tingkat kepuasan pelanggan berbanding terbalik dengan hasil kinerja atribut, Questionable Result apabila tingkat kepuasan pelanggan tidak dapat didefinisikan (terdapat kontradiksi pada jawaban pelanggan) atau Indifferent apabila tingkat kepuasan pelanggan tidak berpengaruh dari hasil kinerja atribut.

Kategori pelanggan diatas akan berubah sesuai dengan perkembangan waktu. Dengan memperhatikan Model Kano, menuntut perusahaan menciptakan produk/jasa inovatif yang dapat menarik perhatian pelanggan diatas Must-be dan One dimensional. Strategi yang dapat diadopsi perusahaan adalah memproduksi produk/ jasa yang mempunyai attractive quality. Strategi ini mengharuskan perusahaan memperhatikan bagaimana menciptakan attractive quality dalam proses pengembangan produk/jasa baru. Langkah-langkah penelitian dengan menggunakan Model Kano adalah :

1. Identifikasi ide/permintaan pelanggan atau menganalisa yang akan diukur.

2. Membuat Kuesioner Kano

Dalam pembuatan Kuesioner yang perhitungannya menggunakan Model Kano maka sifat dari Kuisioner tersebut adalah setiap satu pertanyaan memiliki dua bagian yaitu functional dan disfunctional.
a. I like it that way
b. It must be that way
c. I am neutral
d. I can live with it that way
e. I dislike it that way

Dalam membuat pertanyaan, pertanyaan yang telah diuji terlebih dahulu validitas dan reliabilitasnya. Kelima variabel dalam Kano tersebut termasuk skala Likert, karena memiliki gradiasi dari sangat positif sampai sangat negatif.

Untuk setiap variabel tidak diberi skor dalam pengolahan datanya tetapi mengikuti langkah-langkah yang sesuai dengan Model Kano yaitu dengan menggunakan Tabel Evaluasi Kano pada Tabel 2 di Gambar 1.

3. Memproses hasil jawaban Kuisioner dengan menggunakan Tabulation of Surveys seperti terlihat pada Tabel 3 di Gambar 1, untuk memproses hasil jawaban Tabel Evaluasi Kano.

4. Menganalisa hasil proses. Langkah yang dilakukan dengan memposisikan setiap atribut pertanyaan. 


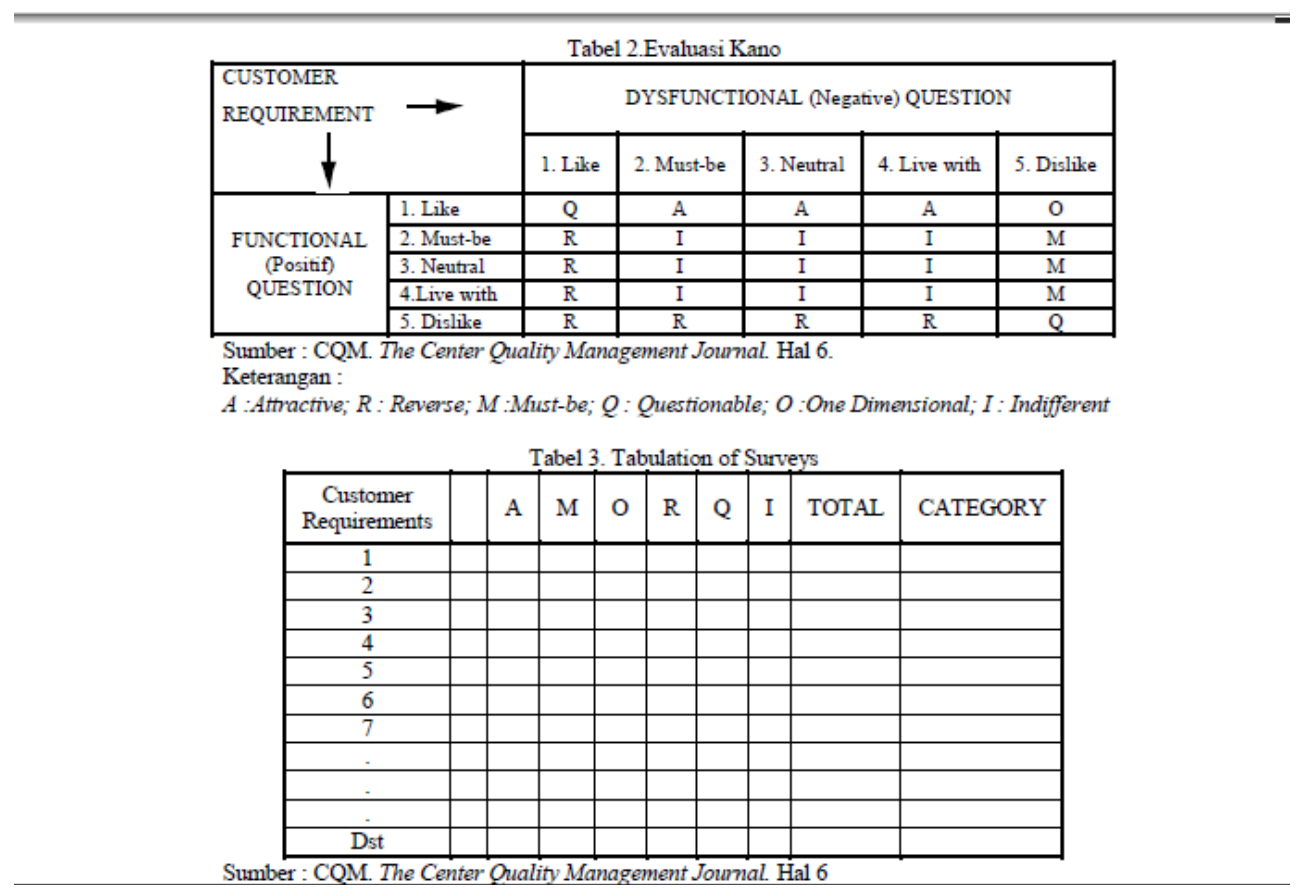

Gambar 1. Tabel Evaluasi Kano dan Tabulation of Surveys

\section{B. Menghitung rata-rata setiap atribut :}

$$
\text { Better }=\frac{A+O}{A+O+M+I} \quad \text { Worse }=-\frac{O+M}{A+O+M+I}
$$

Dari hasil rata-rata dapat diketahui nilai yang memungkinkan mengetahui atribut yang menjadi kepuasan pelanggan dan ketidakpuasan pelanggan. Atribut yang bernilai positif dipertahankan sedangkan yang negatif dilakukan tindakan perbaikan.

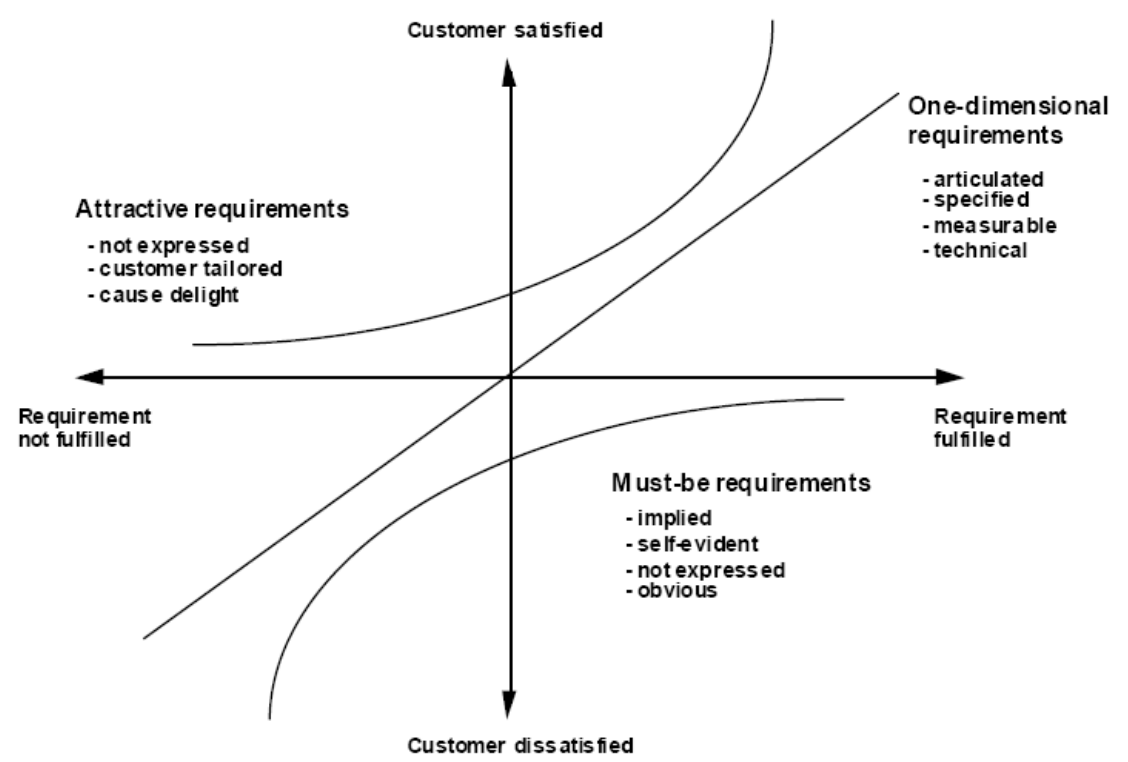

Gambar 2. Customer Satisfied \& Dissatisfied Diagram 


\section{METODOLOGI PENELITIAN}

Penelitian dimulai dengan membagi atau memetakan pembagian layanan di Restauran cepat saji Mc Donald, kemudian menganalisa kebutuhan input data pada model atribut Kano, analisa layanan yang diperoleh diteruskan kedalam atribut Kano. Proses pengambilan data dilakukan dengan metode survey kuesioner, serta melibatkan 30 orang sebagai responden.

\section{HASIL DAN PEMBAHASAN}

Tabel 1. Atribut Pelayanan

\begin{tabular}{|l|l|}
\hline \multicolumn{1}{|c|}{ Pelayanan McD } & \multicolumn{1}{c|}{ Atribut } \\
\hline Pengelolaan Website & 1.Website selalu update \\
\hline Karyawan & $\begin{array}{l}\text { 2. Ramah } \\
\text { 3. Cepat }\end{array}$ \\
\hline Menu & $\begin{array}{l}\text { 4.Sesuai kebutuhan konsumen } \\
\text { 5. Variatif } \\
\text { 6. Memiliki cita rasa yang diinginkan konsumen }\end{array}$ \\
\hline Harga & 7. Terjangkau \\
\hline
\end{tabular}

\begin{tabular}{|l|l|l|l|l|l|l|l|l|l|}
\hline $\begin{array}{l}\text { Cust. } \\
\text { Requirement }\end{array}$ & A & M & O & R & Q & I & Total & Max & Grade \\
\hline 1 & 8 & 6 & 0 & 3 & 0 & 13 & 30 & 13 & I \\
\hline 2 & 7 & 11 & 0 & 7 & 0 & 6 & 30 & 11 & M \\
\hline 3 & 9 & 14 & 0 & 3 & 0 & 4 & 30 & 14 & M \\
\hline 4 & 2 & 3 & 3 & 0 & 0 & 21 & 30 & 21 & I \\
\hline 5 & 0 & 1 & 0 & 15 & 0 & 14 & 30 & 15 & R \\
\hline 6 & 5 & 10 & 0 & 8 & 0 & 7 & 30 & 10 & M \\
\hline 7 & 0 & 14 & 0 & 8 & 0 & 8 & 30 & 14 & M \\
\hline
\end{tabular}

Tabel 2. Perhitungan Berdasarkan Tabel Evaluasi Kano

Dari hasil tabulasi diatas diketahui tingkat kepuasan sebagai berikut:

1. Website selalu update ->Indifferent

2. Pelayanan ramah $->$ Mustbe

3. Cepat $->$ Mustbe

4. Menu yang disediakan sesuai kebutuhan konsumen ->Indifferent

5. Menu variatif ->Reverse

6. Rasa yang ditawarkan sesuai keinginan konsumen ->Mustbe

7. Harga produk terjangkau ->Mustbe

\section{Memposisikan Atribut}

Berdasarkan rumus dibawah ini, yaitu:

$$
\text { Better }=\frac{A+O}{A+O+M+I} \quad \text { Worse }=-\frac{O+M}{A+O+M+I}
$$


Tabel 3. Nilai Extent of Satisfaction and Dissatisfaction

\begin{tabular}{|l|l|l|l|l|l|l|l|l|l|}
\hline $\begin{array}{l}\text { Cust. } \\
\text { Requirement }\end{array}$ & A & M & O & R & Q & I & Total & SI & DI \\
\hline 1 & 8 & 6 & 0 & 3 & 0 & 13 & 30 & 0,30 & $-0,22$ \\
\hline 2 & 7 & 11 & 0 & 7 & 0 & 6 & 30 & 0,29 & $-0,46$ \\
\hline 3 & 9 & 14 & 0 & 3 & 0 & 4 & 30 & 0,33 & $-0,52$ \\
\hline 4 & 2 & 3 & 3 & 0 & 0 & 21 & 30 & 0,17 & $-0,21$ \\
\hline 5 & 0 & 1 & 0 & 15 & 0 & 14 & 30 & 0,00 & $-0,07$ \\
\hline 6 & 5 & 10 & 0 & 8 & 0 & 7 & 30 & 0,23 & $-0,45$ \\
\hline 7 & 0 & 14 & 0 & 8 & 0 & 8 & 30 & 0,00 & $-0,64$ \\
\hline
\end{tabular}

Jika dibuat dalam diagram atribut Kano hasilnya adalah sebagai berikut:

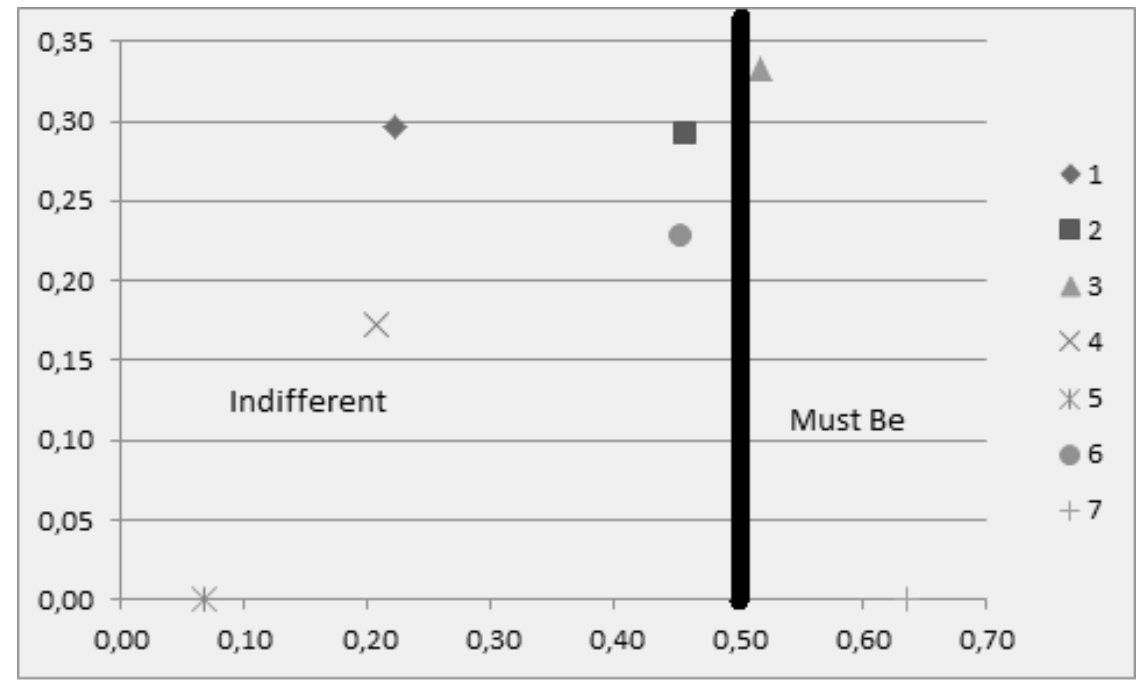

Gambar 3. Diagram Atribut Kano

\section{KESIMPULAN}

Dari hasil tabulasi dengan menggunakan variabel atribut sebagai berikut:

1. Website selalu update $->$ Indifferent

2. Pelayanan ramah -> Must be

3. Cepat -> Must be

4. Menu yang disediakan sesuai kebutuhan konsumen -> Indifferent

5. Menu variatif $->$ Reverse

6. Rasa yang ditawarkan sesuai keinginan konsumen -> Must be

7. Harga produk terjangkau -> Must be

Hasilnya cukup menarik, sebab sebagian besar atribut pelayanan diatas mutlak diinginkan konsumen, seperti pelayanan ramah dan cepat, rasa produk serta harga. Must be berarti jika pelayanan diatas tidak dilakukan dengan baik, maka tingkat kepuasan konsumen akan rendah.

Untuk website serta menu yang disajikan tidak terlalu berarti bagi konsumen. Yang menariknya adalah menu, dimana jika kita menggunakan cara pikir sendiri, tentu menu adalah hal yang harus sesuai kebutuhan mengingat kita ingin mengkonsumsi produk yang menurut kita diinginkan. Namun pada sampel tersebut mungkin tidak menghiraukannya karena berbagai faktor.

Pada variasi menu justru akan berakibat negatif jika McD melakukannya berlebihan. Hal ini bisa disebabkan perilaku konsumen yang tidak menyukai inovasi atau hanya menyukai menu awal dari McD. 


\section{DAFTAR PUSTAKA}

[1] Amitava Mitra, 1998. Fundamentals Of Quality Control And Improvement, Mac Millan Publishing Company.

[2] Supranto J.,1997, Pengukuran Tingkat Kepuasan Pelanggan, Rineka Cipta, Jakarta.

[3] Supranto, J. 2001. Pengukuran Tingkat Kepuasan Pelanggan untuk Menaikkan Pangsa Pasar. Jakarta: PT. Rineka Cipta.

[4] Walden, D. (1993). A Special Issue on Kano's Methods for Understanding Customer Defined Quality. The Center for Quality of Management Journal. Wordpress.com/validitas dan reliabilitas.

[5] Tiena G. Amran Ponti Ekadeputra. Pengukuran Kepuasan Pelanggan Menggunakan Metode Kano dan Root Cause Analysis. 